\title{
Clitorial inclusion cyst in an adult: a rare presentation
}

\section{Tanweerul Huda, Tarun Sutrave, Bharati Pandya*}

Department of General Surgery, AIIMS Bhopal, Bhopal, Madhya Pradesh, India

Received: 14 June 2019

Revised: 26 June 2019

Accepted: 07 July 2019

\section{* Correspondence:}

Dr. Bharati Pandya,

E-mail: bharati_pandya@rediffmail.com

Copyright: (c) the author(s), publisher and licensee Medip Academy. This is an open-access article distributed under the terms of the Creative Commons Attribution Non-Commercial License, which permits unrestricted non-commercial use, distribution, and reproduction in any medium, provided the original work is properly cited.

\begin{abstract}
Dermoid cysts are benign lesions that grow slowly and can occur anywhere in the body. Clitoris is an extremely rare site for dermoids cysts. We present a case of inclusion cyst of clitoris in a middle aged woman, who had it for 10 years before presenting for relief from her symptoms. Local examination revealed a $3 \mathrm{~cm} \mathrm{X} 4 \mathrm{~cm}$ size cystic mass at the clitoris giving it an appearance of clitoromegaly. She underwent an excision of the cyst at our hospital with the histopathology report suggesting the lesion to be a dermoid cyst. Postoperative recovery was uneventful with no evidence of recurrence on follow up.
\end{abstract}

Keywords: Clitorial Cyst, Clitorial dermoids, Epidermoid cyst, Spontaneous dermoids

\section{INTRODUCTION}

Dermoid cysts are benign lesions that grow slowly and can occur anywhere in the body. Epidermoid cysts occur commonly over the face, trunk, scalp, neck and extremities. A mature teratoma is called as a dermoid cyst. Vulva is a rare site, however clitorial and labial cysts have been reported in literature. ${ }^{1,2}$ A preceding history of trauma of some form is associated and very rare cases of clitorial dermoids without history of trauma have also been reported. ${ }^{1,3,4} \mathrm{We}$ present a case of inclusion cyst of clitoris in a middle aged woman, who had it for 10 years before presenting for relief from her symptoms. At the first visit, after gaining the history and following physical examination surgical treatment was advised and patient has been totally asymptomatic after removal.

\section{CASE REPORT}

A 45-year-old, multiparous female presented with no significant past history of trauma, developed a gradually progressive clitorial mass with history of pain and pus discharge off and on for the past two years. She also complained of pain during coitus.

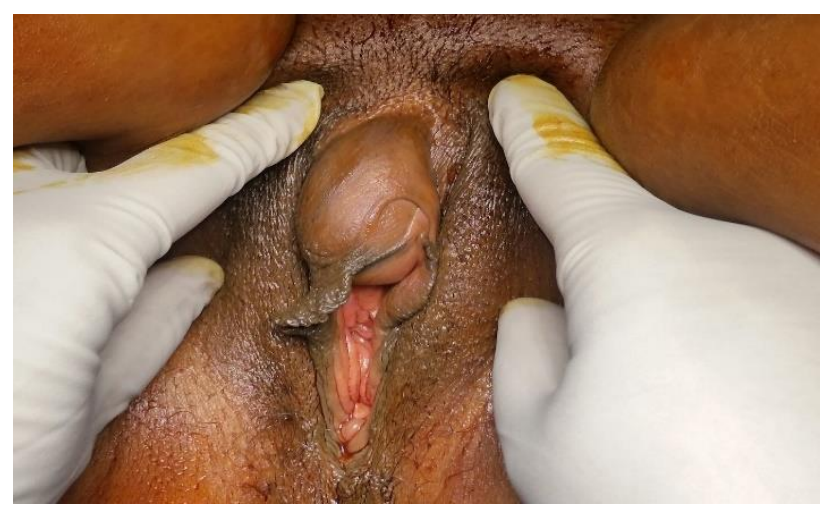

Figure 1: Clinical examination picture showing a large lesion in the clitorial region.

There was no history of hormonal intake, urinary complaints or any other systemic complaints. General 
physical and abdominal examination were normal. On local examination she was found to have a $3 \mathrm{~cm} \mathrm{X} 4 \mathrm{~cm}$ size cystic mass at the clitoris giving it an appearance of clitoromegaly (Figure 1).

On careful examination, near the fold with the labia minora a small scar with pus point was seen. Urethral and vaginal orifices were normal (Figure 2). Her routine investigations and ultrasound study were normal.

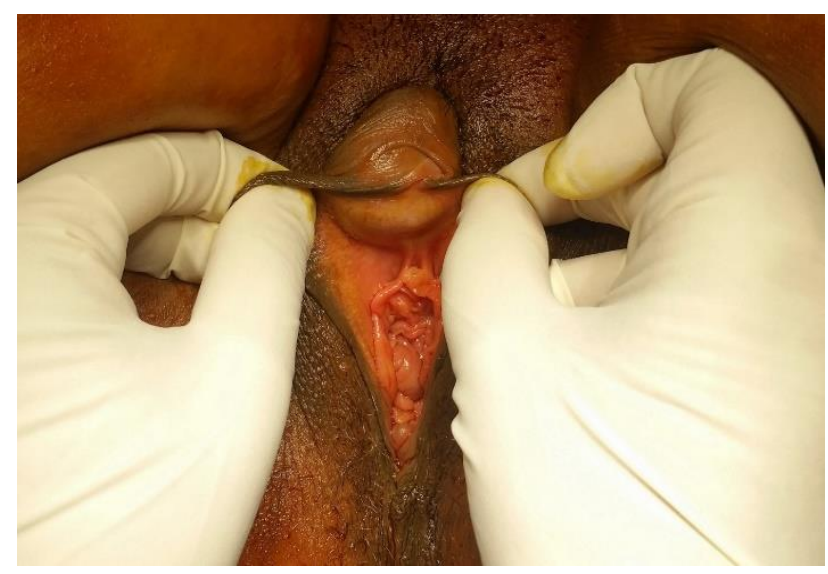

Figure 2: Clinical examination picture showing the cystic lesion from undersurface view. The vaginal opening is seen free from the lesion.

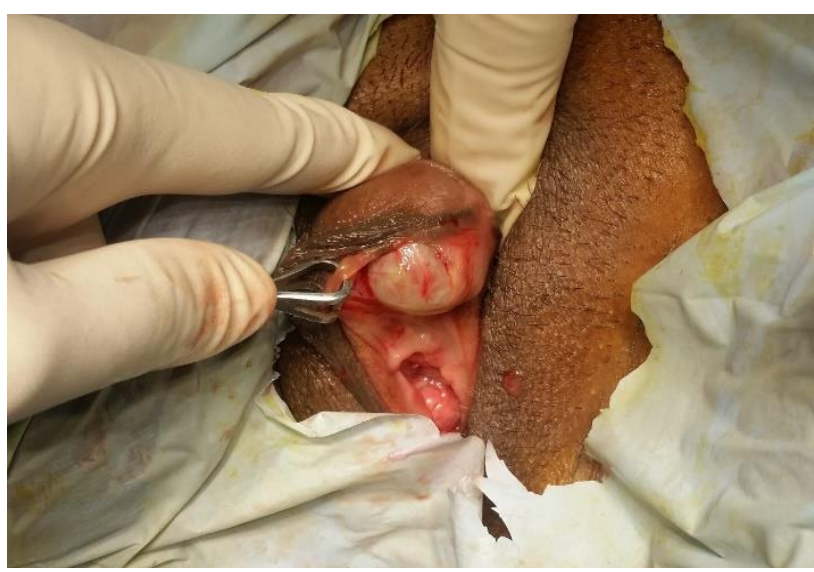

Figure 3: Intraoperative picture showing incision on the undersurface of the labia minoral folds to enucleate the dermoid cyst.

With the clinical diagnosis of a clitorial inclusion cyst, she underwent an excision of the entire cyst under local anesthesia in our hospital. The surgery was simple enucleation of the cyst, at some parts due to previous leaks, there were adhesions and they were meticulously released (Figure 3, 4). The defect was closed primarily (Figure 5). Excised specimen was sent for histopathology (Figure 6). Histopathology revealed it to be a keratinous inclusion cyst. She did well post operatively and was discharged on the second day of surgery. She is doing well after 1 year of the procedure with neither pain nor cosmetic problems.

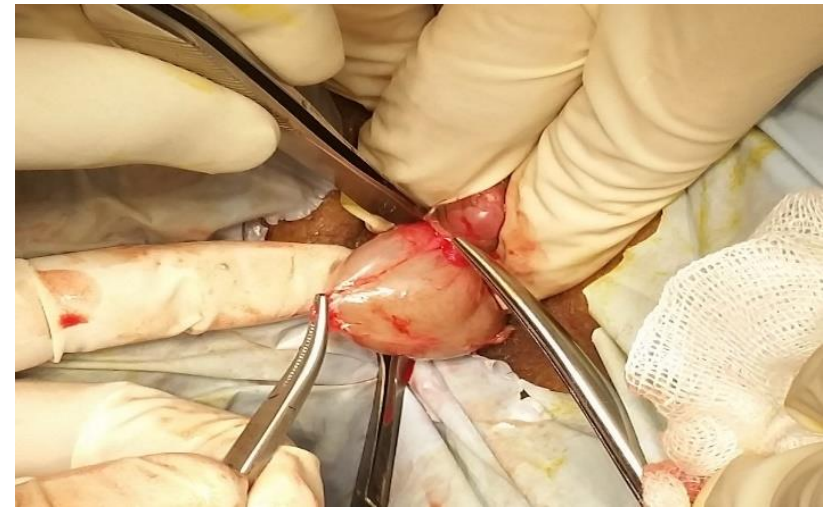

Figure 4: Intraoperative picture showing circumferential dissection of cyst from surrounding structures.

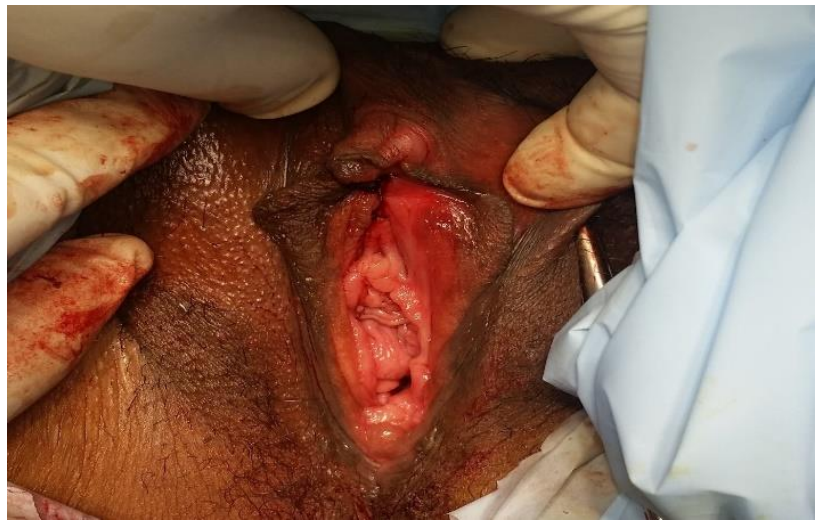

Figure 5: Postoperative picture showing repaired labial defect after enucleation of cyst.

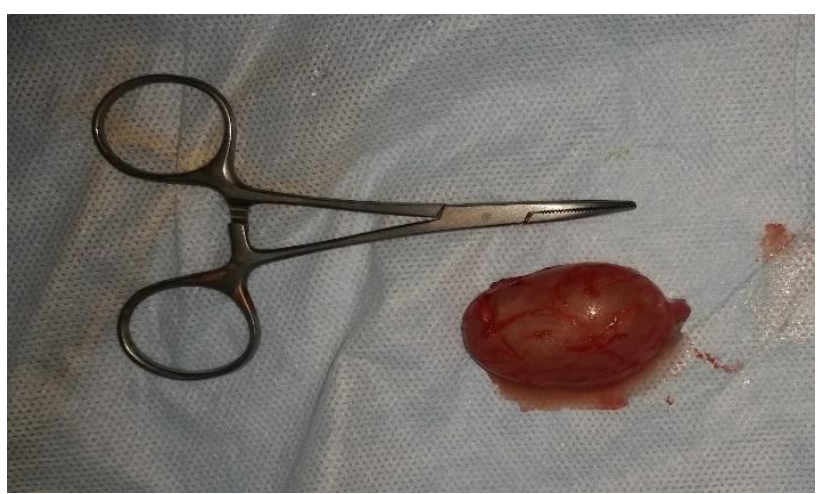

Figure 6: Excised specimen of the cyst.

\section{DISCUSSION}

Clitorial swellings can have a varied etiology. Inclusion cysts without history though reported are very rare. Children and adolescents are more often affected and in older patients the cause is usually traumatic, mostly seen in geographical areas where female circumcision is routinely practiced. ${ }^{1,5,6,8}$ The delayed presentation is usually due to psycho-social inhibition on the part of females to seek medical aid. ${ }^{7,8}$ Our patient had no history 
of preceding trauma and was suffering for 10 years before presenting to us. She was even having intermittent leak from the cyst in the form of copious amount of pus. It also has a psycho-social bearing. In patients whom it is difficult to clinically ascertain the diagnosis, ${ }^{8}$ various tests may be undertaken to rule out other causes of clitoromegaly, especially if the patient is a child as in children it is a clinical challenge to differentiate it from ambiguous genitalia. ${ }^{5}$ Clitorial anomalies or tumors are rare even in childhood and need to be differentiated from ambiguous genitalia and hormonal, gonadal or chromosomal alterations. The variety of clitorial tumors reported include fibroma, leiomyoma, angiokeratoma, pseudolymphoma, hemangioma, lymphangiofibroma, hemangiopericytoma, myiasis, granular cell tumors and neurofibromas, besides cystic lesions. ${ }^{9,10-14}$ Also seen are malignancies include carcinoma, endodermal sinus tumor, sarcoma, rhabdomyosarcoma, schwannoma, epitheloid hemangioendothelioma and lymphoma. ${ }^{15,16}$ Elaborate investigations may be required when diagnosis is uncertain.

The treatment of a dermoid or inclusion cyst is simple excision. In our patient it was done under local anesthesia and even catheter was not required. Patient was totally asymptomatic post operatively and has remained so for the past 1 year. The most important was her sociopsychological relief after the surgery.

\section{CONCLUSION}

Clitorial inclusion cysts in absence of history of trauma are rare and have a wide spectrum of differential diagnosis. The psycho-social impact on the patient has to be taken into account and addressed appropriately. The treatment is simple and proper enucleation of the dermoid results in functional as well as cosmetic satisfaction to the patient.

Funding: No funding sources

Conflict of interest: None declared

Ethical approval: Not required

\section{REFERENCES}

1. Pehlivan M, Özbay PÖ, Temur M, Yılmaz Ö, Gümüş Z, Güzel A. Epidermal cyst in an unusual site: A case report. Int J Surg Case Reports. 2015;8:114-6.

2. N. Kirkham, Tumors and cysts of the epidermis, in: D.E. Elder, R. Elenitsas, B.L. Johnson, G.F. Murphy $\mathrm{Jr}$ (Eds.), Lever's Histopathology of the Skin, 9th ed., Lippincott Williams \& Wilkins, Philadelphia, 2005:805-866.
3. Kroll G, Miller L. Vulvar epithelial inclusion cyst as a late complication of childhood female traditional genital surgery. American J Obstet Gynecol. 2000;183(2):509-10.

4. Gupta S. A "stone" in the vulva. Sexually Transmitted Infections. 2000;76(4):319.

5. Gomes A, Onofre L, Leão J, Leão F, Amaral Cruz T, Sircilli M, et al. Clitoral anomalies not associated with disorders of sex development. Journal of Pediatric Surgery Case Reports. 2013;1(11):403-5.

6. Nayak A, Sarmalkar M, Mehendale M, Shah S. Spontaneous nontraumatic epidermoid cyst of the clitoris: a rare case report. Int $\mathrm{J}$ Reprod Contracept Obstet Gynecol. 2015;4(6):2082.

7. Aggarwal SK, Manchanda V, Pant N. Epidermoid cyst of clitoris mimicking clitoromegaly. J Ind Assoc Ped Surg. 2010;15(1):23-4.

8. El-agwany A. A large clitoral epidermal dermoid cyst: A rare long term complication after female circumcision. Middle East Fertility Soci J. 2015;20(1):57-59.

9. Geramizadeh B, Anbardar MH, Shakeri S. Clitoromegaly caused by cavernous hemangioma: A rare case report and review of the literature. Urol Ann. 2012;4(3):175-7.

10. Brock III JW, Morgan W, Anderson TL. Congenital hemangiopericytoma of the clitoris. The $\mathrm{J}$ urol. 1995;153(2):468-9.

11. Kudur MH, Pooja M, Nayak S. Unusual presentation of cutaneous myiasis. Ind J Dermatol, Venereol, Leprol. 2010;76(6):712.

12. Pascual-Castroviejo I, Lopez-Pereira P, Savasta S, Lopez-Gutierrez JC, Lago CM, Cisternino M. Neurofibromatosis type 1 with external genitalia involvement: Presentation of 4 patients. J Ped Surg. 2008;43(11):1998-2003.

13. Çelik N, Yalçin S, Güçer S, Karnak İ. Clitoral epidermoid cyst secondary to blunt trauma in a 9year-old child. The Turkish J ped. 2011;53(1):108.

14. Maor-Sagie E, Arbell D, Prus D, Israel E, Benshushan A. Pilonidal cyst involving the clitoris in an 8-year-old girl- a case report and literature review. J ped surg. 2010;45(11):e27-9.

15. Gazic B, Sramek-Zatler S, Repse-Fokter A, Pizem J. Pilomatrix carcinoma of the clitoris. International $\mathbf{J}$ Surg Pathol. 2011;19(6):827-30.

16. Al-Tonbary Y, Zalata K, Sarhan M, El-Ashery R, Fouda A. Rhabdomyosarcoma of the clitoris. Hematology/oncology and stem cell therapy. 2008;1(2):133-5.

Cite this article as: Huda T, Sutrave T, Pandya B. Clitorial inclusion cyst in an adult: a rare presentation. Int J Reprod Contracept Obstet Gynecol 2019;8:3374-6. 